\title{
Phenotypic Characteristics of Shahi Strain of Nagpuri Buffaloes in Chandrapur District of Maharashtra, India
}

\author{
H.S. Hamand ${ }^{1}$, R.M. Zinjarde ${ }^{1, *}$, S.N. Rokde ${ }^{2}$ and N.S.Chore ${ }^{1}$ \\ ${ }^{1}$ Animal Husbandry \& Dairy Science Department, College of Agriculture, Nagpur, Dr Panjabrao Deshmukh \\ Krishi Vidyapeeth, Akola, Maharashtra, India \\ ${ }^{2}$ Principal Scientist (LP\&M) ICAR, CICR, Nagpur, India
}

\begin{abstract}
Phenotypic Characterization of Shahi Strain of Nagpuri Buffaloes was done in the Chandrapur District of Maharashtra, India. Two hundred and forty Shahi strain of Nagpuri female buffaloes of various age groups were observed in their home tract ( $\mathrm{n}$ farms=24). It was found that black coat colour, black coloured muzzle, white patches on the legs, whitish eyes, white coloured tail switch, horizontal ear orientation, sword-shaped horns with pointed tip first turning backwards and then upwards, bowl-shaped udder are typical characteristics of this breed. The average live body weight, body length, chest girth, height at withers, head length, breadth of head of these buffaloes is (means \pm standard deviation) $433 \pm 8.4 \mathrm{~kg}, 137.08 \pm 2.78 \mathrm{~cm} 180.81 \pm 3.84 \mathrm{~cm}, 129.43 \pm 2.26 \mathrm{~cm}, 54.18 \pm 1.10 \mathrm{~cm}, 28.18 \pm 0.34 \mathrm{~cm}$ in 3 years and above age group, respectively. The average daily milk yield and milk yield per lactation of Shahi strain of Nagpuri buffaloes were observed to be $4.06 \pm 0.08 \mathrm{~kg}$ and $1,220.84 \pm 41.57 \mathrm{~kg}$, respectively.
\end{abstract}

Keywords: Nagpuri Buffaloes, Shahi strain, Phenotypic, Production, Breed Characterization.

\section{INTRODUCTION}

India has the highest number of buffalo breeds in the world [1]. In India there are 13 descript recognized buffalo breeds and non-descript buffalo breeds in the country which have regional importance and add to the economic value of the farming community (http:/www.nbagr.res.in/rejbuf.html) Nagpuri is one of them. This breed is also known as Berari breed of buffaloes, recognized as early as 1938 [2]. It belongs to Vidarbha region of Maharashtra state in India. It is a light but strong and hardy dual-purpose breed of buffaloes which is adapted to hilly and forest areas of the tropical climate. There are five distinct strains of Nagpuri buffaloes spread over five districts of Vidarbha region of Maharashtra state in India viz. Purnathadi (having home tract along the banks of Purna river in Akola district ), Ellichpuri (having home tract in Achalpur Tehsil of Amravati district ), Gaolao or Guali (having home tract in Wardha district ), Nagpuri (having home tract in Nagpur district) and Shahi (having home tract in Chandrapur district). [3] and [4] also recognized different strains of Nagpuri buffaloes differing in colour and body characteristics. But due to indiscriminate breeding, their genetic potential is jeopardized. Large herds of these non-descript buffalo breeds are found in Deccan plains [5]. Hence, their evaluation, conservation and genetic improvement have become increasingly important. Further, breed characterization

\footnotetext{
*Address correspondence to this author at the Animal Husbandry \& Dairy Science Department, College of Agriculture, Nagpur, Dr Panjabrao Deshmukh Krishi Vidyapeeth, Akola, Maharashtra, India; Tel: 9422189627 ;

Fax: 0712-2554820; E-mail: Zinjarde.rm@gmail.com
}

can serve as a guide for proper identification of the breed and help in planning for improvement in growth, reproductive and productive performance. There are very few reports on these aspects. Therefore, the present investigation was undertaken during the year 2013 to study the habitat, phenotypic appearance, breed characteristics, biometric measurements and productive performance of Shahi strain of Nagpuri buffaloes in Ballarsha and Chimur tehsils of Chandrapur district of Maharashtra, India (18.40 to 20.50 North latitude and 78.50 to 80.60 East longitude).

\section{MATERIALS AND METHODS}

For a collection of primary data, a questionnaire was specifically developed. It was pretested and subsequently used for the survey. The data pertaining to the biometric measurements were collected personally by taking direct observations from 240 Shahi strain of Nagpuri female buffaloes of various age groups in their home tract ( $\mathrm{n}$ farms $=24$ ). The data were categorized into various age groups viz. Group A (up to 1 year age; $n=6$ ), Group $B$ (age ranging between 1 to 2 years; $n=6$ ), Group $C$ (age ranging between 2 to 3 years; $n=6$ ) and Group D (age 3 years and above; $n=6)$. The data were tabulated and analysed by standard statistical techniques and chi-square test [6].

\section{RESULTS AND DISCUSSION}

\section{Phenotypic Characteristics}

\section{Coat Colour}

It was observed that, out of 240 Shahi subjects, the majority $(88.75 \%)$ exhibited a black coat colour and 
the remaining had brown coat colour. Similarly, [7] and [8] reported that the percentage of Nagpuri buffaloes having black coat colour were 91.50 and $92.50 \%$, respectively. [9] also reported that $92 \%$ of the Ellichpuri strain of Nagpuri buffaloes had a black coat. Further, [5] observed that $80-90 \%$ of the Ellichpuri strain of Nagpuri buffaloes had black coat colour. The chi-square value was 144.15 indicating that there is a variation in coat colour between various age groups and black coat is a typical characteristic of this breed.

\section{Muzzle Colour}

The majority $(76.25 \%)$ of subjects had a black muzzle, [7] and [8] also obtained similar results. [9] also reported that $65 \%$ of Ellichpuri strain of Nagpuri buffaloes had a black coloured muzzle, whereas, [10] reported that $70 \%$ of the Gaolao strain of Nagpuri buffaloes had a black muzzle. The chi-square value was 66.15 indicating that there is a variation in colour of muzzle between various age groups and the black muzzle is a typical characteristic of this breed.

\section{Colour of the Patch on Legs}

Most of the subjects $(82.08 \%)$ had a white patch on their legs and $5.83 \%$ had a brown patch on their legs, whereas the remaining (12. $08 \%$ ) had no patch on their legs. Similar results were obtained by [10 and [11] ].

\section{Colour of the Eye}

The colour of eyes of the majority $(56.66 \%)$ of the animals was whitish, whereas 33.75 and $9.58 \%$ had black and brown eyes, respectively. Similarly, [10] reported that $56.80 \%$ Gaolao strain of Nagpuri buffaloes had whitish eye colour. [5] also observed that $56.60 \%$ of Nagpuri buffaloes had whitish eyes. The chi-square value was 79.82 showing that there is a variation of eyes colour between various age groups and whitish eyes is a typical characteristic of this breed.

\section{Colour of the Switch of Tail}

The colour of switch of the tail of the majority of the animals (58.75\%) was white, whereas 33.75 and 7.5 $\%$ had a black and brown switch of the tail, respectively. Similarly, [10] reported that $60.40 \%$ Gaolao strain of Nagpuri buffaloes had a whitish coloured tail switch. [8] and [9] also reported that 55 per cent of Ellichpuri strain of Nagpuri buffaloes had a white coloured tail switch. But [12] reported a higher percentage (75.80) of Ellichpuri strain of Nagpuri buffaloes had a white coloured tail switch. The chisquare value was 94.57 indicating that there is a variation in colour of tail switch between various age groups and white coloured tail switch is a typical characteristic of this breed.

\section{The Orientation of Ears}

It was observed that $74.50 \%$ of subjects had horizontal ear orientation, whereas the remaining had drooping ears. Similarly, [10] reported that the orientation of ears in $76 \%$ of Gaolao strain of Nagpuri buffaloes was horizontal. The percentage of Ellichpuri strain of Nagpuri buffaloes having horizontal ear orientation reported by [5] was somewhat higher ( 80.40 $\%)$ and the percentage of Bhadawari buffaloes having horizontal ear orientation reported by [13] was lower $(59.00 \%)$. The chi-square value was 58.02 indicating that there is a variation in ear orientation between various age groups and horizontal ear orientation is a typical characteristic of this breed.

\section{The Shape of Horns}

The majority $(76.25 \%)$ of animals had swordshaped horns with a pointed tip and $18.33 \%$ buffaloes had sickle-shaped horns. Similar results were obtained by [10] in Gaolao strain of Nagpuri buffaloes. But [5] reported a higher percentage (87.20) of Ellichpuri strain of Nagpuri buffaloes with sword-shaped horns. [14] and [15] also obtained similar results in Nagpuri buffaloes.

\section{The Orientation of Horns}

The horns of the majority of subjects $(81.66 \%)$ were first turning backwards and then upwards. Similar results were obtained by [5] in Gaolao strain of Nagpuri buffaloes, whereas in Ellichpuri strain $87.20 \%$ of subjects had a sword-like the orientation of horns [5].

\section{The Shape of Udder}

The percentage of Shahi strain of Nagpuri buffaloes which had bowl-shaped udder was $71.66 \%$ followed by round-shaped udder (15\%) and goat type udder (13.34 $\%)$. [13] reported bowl-shaped udder in $74 \%$ of Bhadawari buffaloes. In Pandharpuri buffaloes [16] reported that $38 \%$ had trough-shaped udder, whereas in Gaolao strain the percentage was 52.6 [10]. The chisquare value was 39.7 indicating that there is a variation in the shape of udder between various age groups and bowl-shaped udder is a typical characteristic of this breed.

\section{Biometric Measurements}

\section{Live Body Weight}

It was observed that the average live body weight (LBW) of Shahi strain of Nagpuri buffaloes was $433 \pm$ 
$8.42 \mathrm{~kg}$ in 3 years and above age group. [17] reported in Nagpuri buffaloes a lower LBW (400 kg) and [5] observed in Ellichpuri strain of Nagpuri buffaloes an LBW of $407.11 \pm 1.63 \mathrm{~kg}$, whereas [10] reported in Gaolao strain a lower LBW $(374.31 \pm 0.31 \mathrm{~kg})$.

\section{Body Length}

The body length 3 years and above age group was $137.08 \pm 2.78 \mathrm{~cm}$. This result is comparable with [5], who reported in Gaolao strain a lower body length $(131.42 \pm 0.83 \mathrm{~cm})$, whereas [18] found in Marathwadi buffaloes a lower body length $(133.38 \pm 0.31 \mathrm{~cm})$. However [9], reported in Guali strain a higher body length $(205.83 \pm 2.15 \mathrm{~cm})$.

\section{Chest Girth}

The chest girth of 3 years and above age group was $180.81 \pm 3.84 \mathrm{~cm}$. This is in close agreement with [5], who observed that the chest girth in Ellichpuri strain was $184.56 \pm 0.27 \mathrm{~cm}$. Besides, these results are in close agreement with [18], who reported in Marathwadi buffaloes a chest girth of $182.95 \pm 0.70 \mathrm{~cm}$. However, [19] reported in Nagpuri buffaloes a higher chest girth $(218.4 \mathrm{~cm})$.

\section{Height at Withers}

The average height at withers of 3 years and above age group was $129.43 \pm 2.26 \mathrm{~cm}$ in. This is in close agreement with [5], who reported that the height at withers of Gaolao strain was $127.43 \pm 0.42 \mathrm{~cm}$. Similar results were obtained in Nagpuri buffaloes by [20], who reported that the height at withers was $127.8 \mathrm{~cm}$

\section{Head Length}

The average head length of 3 years and above age group was $54.18 \pm 1.10 \mathrm{~cm}$ in. The results of the present study are in close agreement with [5], who reported that the head length of Ellichpuri strain was $53.08 \mathrm{~cm}$, whereas [7] reported in Nagpuri buffaloes a lower $(51.51 \mathrm{~cm})$ head length. However, [10] reported in Gaolao strain higher head length $(57.67 \pm 0.68 \mathrm{~cm})$.

\section{Breadth of Head}

The average head length of 3 years and above age group was $28.18 \pm 0.34 \mathrm{~cm}$. [11] observed in Gaolao strain a lower head breadth $(20.80 \pm 1.03 \mathrm{~cm})$.

\section{Production Traits}

\section{Average Daily Milk Yield}

The average daily milk yield of Shahi strain of Nagpuri buffaloes was observed to be $4.06 \pm 0.08 \mathrm{~kg}$.
This result is in close agreement with [5], who reported that the average daily milk yield of Ellichpuri strain of Nagpuri buffaloes was $4.08 \pm 0.05 \mathrm{~kg}$. However [10], observed in Gaolao strain a comparatively less average daily milk yield $(3.82 \pm 0.092 \mathrm{~kg})$. [1] reported in Bhadawari buffaloes a higher average daily milk yield $(6.96 \mathrm{~kg})$.

\section{Milk Yield Per Lactation}

The milk yield per lactation was 1,220.84 \pm 41.57 $\mathrm{kg}$. This result is similar to that observed by [10] in Gaolao strain (1,212 .84 \pm 17.33). However, in Ellichpuri strain a lower milk yield per lactation $(1,181.61 \pm 13.90 \mathrm{~kg})$ was found by [5], whereas [21] observed in Nagpuri buffaloes a lower milk yield per lactation $(1,023.19 \mathrm{~kg})$. [1] reported that the milk yield per lactation of Bhadawari buffaloes was $1,250.5 \mathrm{~kg}$.

\section{CONCLUSIONS}

The breed characterization of Shahi strain of Nagpuri buffaloes can serve as a guide for proper identification of the breed and help in conservation and planning for improvement in growth, reproductive and productive performance. If modern, scientific feeding and management practices are adopted then this breed can perform even better and prove to be a promising breed for Vidarbha region of Maharashtra state in India.

\section{ACKNOWLEDGEMENTS}

The authors are very thankful to the Head, Animal Husbandry \& Dairy Science Division and Associate Dean, College of Agriculture, Nagpur under Dr PDKV, Akola, for providing all necessary facilities and cooperation for conducting the present investigation.

\section{REFERENCES}

[1] Kushwaha BP, Sultan Singh, Das N, Maity SB, Singh KK, Jayasankar J. Production and reproductive performance of Bhadawari buffaloes in Uttar Pradesh, India. J Buffalo Science 2013; 2: 72-77.

https://doi.org/10.6000/1927-520X.2013.02.02.3

[2] Oliver A. A brief survey of some of the important breeds of buffaloes in India Miscellaneous Bulletin 17 ICAR, India. 1938.

[3] Rife DC. The water buffaloes of India and Pakistan International cooperation. Washington DC. Administration 33. 1959.

[4] Ranjan SK, Pathak NN. Management and feeding buffalo 2nd edition Vikas Publishing House Ltd. New Delhi, India 1983; pp. 43.

[5] Lokhande NS, Zinjarde RM, Gajarawar GS, Ingole AS. Phenotypic characterization of Ellichpuri strain of Nagpuri buffaloes. Indian J Dairy Science 2011; 64(4): 323-325.

[6] Snedecor GW, Cochran WG. Statistical Methods, 8th Ed. East-West Press Pvt. Ltd. New Delhi 1994; 217-232. 
[7] Chafle SR. Studies on some physical characters and milk production of Nagpuri buffalo breed. M.Sc. Thesis. Dr Panjabrao Deshmukh Krihi Vidyapeeth, Akola, Maharashtra (India) 1992.

[8] Shrikhande RK, Kolte AY, Kolte BR. Phenotypic characteristics of Nagpuri (Berari) buffaloes. Indian Veterinary J 1996; 73(11): 1198-1199.

[9] Kolte AY, Sadekar RD. Phenotypic characteristics of Guali strain of Nagpuri buffaloes. Indian Journal of Animal Science 1996.

[10] Tayde UD, Zinjarde RM, Rokde SN, Ingole AS. Phenotypic characteristics of Gaolao strain of Nagpuri (Berari) buffaloes in Wardha district of Maharashtra, India. Indian J Animal Sciences India) 2010; 80 (1): 67-68.

[11] Bire PV, Tambat RV, Ramekar BW. Purnathadi buffalo. A strain of Berari breed-potential animal for milk production. Livestock Advisor 1994; 19(12): 28-36.

[12] Patil VP, Ulmek BR. Phenotypic characteristics of Pandharpuri buffaloes Proceedings of the 4th Asian Congress on buffaloes for food security and rural development New Delhi 2002; 2: 109.

[13] Singh HN, Goel R, Sharma KC, Kumar S. Phenotypic variation in morphological features and performance of Bhadawari buffaloes. Compendium of papers. National Seminar on the Selection of Breeding Bulls 2004; 15: 67- 68.
[14] Kadu MS, Khire DW, Ali SZ. Nagpuri (Berari) buffaloes. Directorate of Extension Education Publication. Dr Panjabrao Deshmukh Krihi Vidyapeeth, Akola, Maharashtra (India). 1977; pp. 28.

[15] Whyte RO, Mathur ML. The buffalo in India Indian Dairyman 1994; 18: 161-165.

[16] Radekar BA, Ulmek BR, Deokar DK, Frande MB. Studies on udder measurement traits of Pandharpuri buffaloes 2003.

[17] Chauhan DS, Thobre BM, Mitkari KR, Rotte SG. A Textbook of Livestock Production and Management. Jagrani Publications. Bhoskar (MS) India pp. 47- 49.

[18] Kalyankar SD. Performance of Marathwadi buffaloes in Parbhani district. M.Sc. Thesis. Marathwada Agricultural University, Parbhani, Maharashtra, India 2001.

[19] Randhawa MS. Agriculture and Animal Husbandry in India ICAR Publication, New Delhi India 1988; pp. 298-301.

[20] Ali SZ, Narkhed PD, Jawade PW. Studies on the influence of lactation on various body measurements of Ellichpuri buffaloes. Livestock Advisor 19(1): 3-7.

[21] Khire DW, Kadu MS, Belorkar PM, Thatte VR, Kaikini AS. Breeding efficiency and producing ability of Nagpuri (Berari) buffaloes (India) Indian J of Animal Sciences (India) 1977; 53(4): $413-414$.

\section{DOI: https://doi.org/10.6000/1927-520X.2019.08.03.4}

(C) 2019 Hamand et al.; Licensee Lifescience Global.

This is an open access article licensed under the terms of the Creative Commons Attribution Non-Commercial License (http://creativecommons.org/licenses/by-nc/3.0/) which permits unrestricted, non-commercial use, distribution and reproduction in any medium, provided the work is properly cited. 